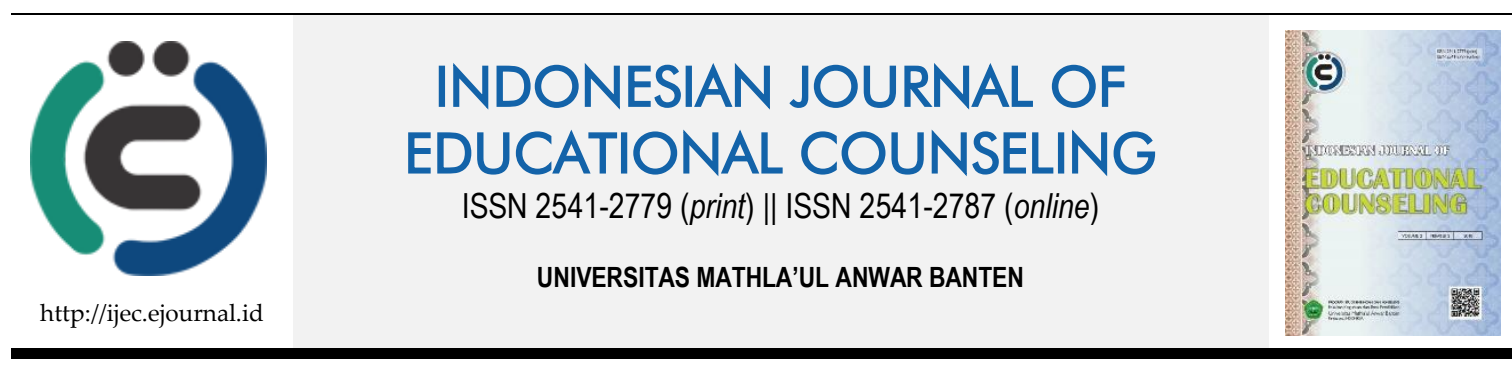

Research Based Article

\title{
Kepemimpinan dan Kepercayaan (Trust) Terhadap Komitmen Organisasi Pada Guru Bimbingan dan Konseling di SMP
}

\author{
Hegar Harini ${ }^{1}$ \\ ${ }^{1}$ STKIP Kusumanegara
}

\begin{tabular}{|c|c|}
\hline ARTICLE INFO & ABSTRACT \\
\hline $\begin{array}{l}\text { Article History: } \\
\text { Received 30.11.2017 } \\
\text { Received in revised } \\
\text { form 12.06.2018 } \\
\text { Accepted } 17.07 .2018 \\
\text { Available online } \\
24.07 .2018\end{array}$ & $\begin{array}{l}\text { The objective of this research is aimed at obtaining the information that related } \\
\text { to the effects of leadership, trust and the organizational commitment, of the } \\
\text { teacher of junior high school in Pasar Minggu District, South of Jakarta. The } \\
\text { method used ia a survey by structured interview with a sample of } 22 \text { school } \\
\text { counselors of junior high school in Pasar Minggu District, South of Jakarta. The } \\
\text { data collected were processed by path analysis. The result proved that the trust } \\
\text { was directly affected by leadership. There are direct effects of the leadership on } \\
\text { organizational commitment and there are direct effects of the trust on } \\
\text { organizational commitment. However, there is an indirect effect of leadership } \\
\text { on organizational commitment through trust. The result can be concluded that } \\
\text { two factors should be considered in the improvement of the organizational } \\
\text { commitment. }\end{array}$ \\
\hline
\end{tabular}

Keywords: Leadership, Organization Commitment, Trust.

DOI: $10.30653 / 001.201822 .44$

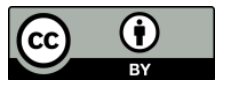

This is an open access article distributed under the terms of the Creative Commons Attribution 4.0 International License, which permits unrestricted use, distribution, and reproduction in any medium, provided the original work is properly cited. ○) 2018 Hegar Harini.

\section{PENDAHULUAN}

Globalisasi menuntut penyelenggaraan pendidikan bermutu dan berkualitas dimana tidak hanya berlaku lokal tetapi juga berlaku interlokal, bahkan internasional. Berbicara tentang mutu banyak presepsi yang mengambarkan mutu. Ada yang melihatnya dari segi kualitas ada yang melihatnya dari segi kuantitas. Menurut laporan The United Nations Development Programme (UNDP) tahun 2011 yang mengumumkan peringkat Indeks Pembangunan Manusia (IPM) atau Human Development Index (HDI) Indonesia menduduki posisi 108 pada tahun 2010. Pada tahun 2012 mengalami penurunan menjadi peringkat 124. Itu artinya pendidikan di Indonesia pada tahun 2012 mengalami kemerosotan yang sangat drastis 16 (enam belas) peringkat. Mutu pendidikan sangat ditentukan oleh banyak pihak, diantaranya pemerintah, masyarakat, sekolah, 
orangtua dan siswa itu sendiri. Akan tetapi kita tidak menginginkan rendahnya mutu pendidikan disebabkan oleh pihak sekolah atau guru, dan guru seringkali dijadikan kambing hitam dari persoalan rendahnya mutu pendidikan. Idealnya semua pihak yang terlibat dalam pendidikan, haruslah bekerja secara profesional. Walaupun demikian guru dan pimpinan sekolah tetaplah menjadi pihak yang paling bertanggung jawab dalam penyelenggaraan pendidikan di sekolah.

Guru selalu menjadi sorotan ketika mutu pendidkan turun, berbagai media massa banyak mengasumsikan bahwa penyebab rendahnya mutu pendidikan adalah komitmen organisasi guru belum sesuai harapan dan lembaga pendidikan yang tidak berhasil dalam proses mewujudkan pendidikan bermutu. Sekolah Menengah Pertama dalam hal ini sebagai suatu organisasi yang melaksanakan proses pendidikan dalam tatanan mikro menempati posisi penting, karena pada lembaga ini masyarakat dapat memperoleh pendidikan dasar untuk mempersiapkan diri dengan pengetahuan dan keterampilan dasar guna melanjutkan pendidikan ke jenjang yang lebih tinggi.

Kemampuan seorang guru dalam mendidik, mengajar dan menjadi teladan bagi murid-muridnya, merupakan salah satu kunci keberhasilan dunia pendidikan kita. Dedikasi seorang guru untuk mencerdaskan anak didiknya, merupakan wujud nyata integritas guru terhadap pendidikan di tanah air. Oleh karena itu, diperlukan adanya faktor-faktor pendukung seperti kepemimpinan dan kepercayaan yang memadai sehingga diharapkan dapat tercapai komitmen organisasi yang maksimal pada guru. Komitmen organisasi tidak akan dapat diwujudkan jika dalam organisasi sekolah tersebut tidak ada kepemimpinan yang baik dan kepercayaan yang tinggi dari personil yang ada di sekolah.

Guru termasuk di dalamnya guru bimbingan dan konseling (BK) atau konselor akan memiliki komitmen kerja yang tinggi apabila ditunjang oleh kepemimpinan yang kuat dari kepala sekolah dan adanya kepercayaan terhadap kepemimpinan tersebut, sehingga guru BK akan memiliki motivasi yang tinggi untuk berprestasi dan berkreativitas karena merasa tujuan organisasi adalah tujuannya juga. Dengan kepemimpinannya seorang kepala sekolah akan mampu menghasilkan keputusan-keputusan kelembagaan sebagai keputusan bersama atau partisipatif antara kepala sekolah, guru, siswa, orangtua siswa, para ahli dan orang-orang yang terlibat secara langsung ataupun tidak langsung dengan lembaga pendidikan yang dipimpinnya. Hal ini secara langsung akan membawa dampak positif terhadap lingkungan kerja yang kondusif bagi guru BK, sehingga akan mendorong guru BK untuk bekerja maksimal dan berkomitmen positif terhadap organisasi, yang berakibat semakin berkomitmen untuk bekerja. Penting bagi guru BK untuk dapat berkomitmen tinggi terhadap pekerjaannya, sehingga menjadikan optimal dalam memberikan pelayanan bimbingan dan konseling guna membantu setiap peserta didik.

Untuk itu penting mengelola komitmen organisasi secara baik agar menghasilkan komitmen organisasi yang tinggi. Komitmen organisasi yang tinggi dari masing-masing anggota organisasi dapat dijadikan tolak ukur keberhasilan dan efektifitas sebuah organisasi dalam memenajemen organisasinya. Sebaliknya jika komitmen organisasi para anggota rendah maka itu akan mendorong para anggota organisasi menjadi malas, rendah prestasi kerja, kurang disiplin, dan tidak kreatif, sehingga dengan sendirinya akan merusak kondisi organisasi dan menghalangi pencapaian tujuan organisasi. Berdasarkan latar belakang di atas peneliti memandang penting dan perlu untuk meneliti pengaruh kepemimpinan dan kepercayaan terhadap komitmen organisasi. 


\section{Kepemimpinan}

Kepemimpinan menurut Robbins dan Judge (2011, p. 410) adalah kemampuan untuk mempengaruhi suatu kelompok untuk mencapai visi dan tujuan yang ditetapkan. Sedangkan Colquitt (2010, p. 441) menyatakan bahwa kepemimpinan adalah penggunaan kekuasaan (power) dan pengaruh untuk mengarahkan aktivitas pengikut terhadap pencapaian tujuan. Lebih lanjut Colquit et al (2011, p. 441) menyebut kekuasaan sebagai kecakapan untuk mempengaruhi perilaku orang lain dan menolak pengaruh yang tidak diinginkan. Hal senada diungkapkan oleh McShane dan Glinow (2008, p. 342) bahwa kekuasaan adalah kapasitas seseorang dalam tim atau organisasi untuk mempengaruhi orang lain. Kekuasaan bukanlah seni merobah orang lain secara perilaku dan kepribadian, tetapi hanya melakukan hal-hal yang bermakna (potensial). Sedangkan Greenberg mengartikan kepemimpinan sebagai proses dimana seorang individu mempengaruhi orang lain dengan berbagai cara agar dapat mencapai tujuan kelompok atau organisasi. Lebih lanjut Greenberg (2010, p. 312) menyebut dasar untuk kekuasaan pemimpin adalah diakui posisinya secara formal serta ditangapi secara kualitas pribadinya oleh para pengikut. Yukl (1994, p. 199) mengungkapkan, bahwa kekuasaan adalah kapasitas seseorang (agen) untuk mempengaruhi orang lain (target).

\section{Kepercayaan}

Andre (2008, p. 186) menyatakan kepercayaan (trust) adalah dasar untuk berkomunikasi efektif. Secara konsep psikologis dan sosiologis, kepercayaan sebagai ciri individual yang dapat dipahami dalam konteks hubungan individu ke individu lain (one to-one), kelompok, dan organisasi. Sementara Colquitt, Lepine, dan Wesson (2011, p. 219) mendefinisikan kepercayaan sebagai bentuk kesediaan (willingness) untuk patuh (vulnerable) kepada pimpinan (otoritas) berdasarkan harapan positif tentang tindakan dan tujuan pimpinan tersebut. Kepercayaan menurut Robbins dan Judge (2011, p. 429) merupakan harapan positif bahwa orang lain tidak akan berbuat oportunistik melalui perkataan, tindakan, atau keputusan.

Sementara Kreitner dan Kinicki (2008, p. 235) menyebut kepercayaan sebagai keyakinan yang bersifat timbal balik dalam tujuan dan perilaku orang lain. Pendapat tersebut sejalan dengan McShane dan Von Glinow (2008, p. 120) yang menyatakan kepercayaan mengacu pada harapan positif satu orang terhadap orang lain dalam situasi yang melibatkan risiko. kepercayaan berarti menempatkan keyakinan pada orang lain atau kelompok. itu juga merupakan kegiatan timbal balik: untuk menerima kepercayaan, seseorang harus menunjukkan kepercayaan pada orang lain. Greenberg (2008, p. 195) menambahkan bahwa kepercayaan adalah derajat keyakinan seseorang dalam ucapan dan tindakan.

\section{Komitmen Organisasi}

Menurut Mowday dan Steer yang dikutip oleh Colquitt (2009, p. 67), komitmen organisasi adalah hasrat atau keinginan dari karyawan untuk menjadi anggota atau bagian dari organisasi. Mendukung pernyataan tersebut, Colquitt (2009, p. 67) berpendapat bahwa komitmen organisasi akan mempengaruhi hasrat pada diri karyawan untuk tetap menjadi bagian dari anggota sebuah organisasi. menyatakan, Komitmen organisasi menurut Mc Shane (2008, p. 119) mengacu pada keterikatan emosional staf/karyawan, mengidentifikasi dan melibatkan diri dengan organisasi/lembaganya. Hal tersebut sejalan dengan Andre (2008, p. 50) yang mendefinisikan komitmen organisasi sebagai keterikatan emosional dan identifikasi seseorang dengan organisasinya. 
Sementara Robbins dan Judge (2011, p. 111) yang menyatakan bahwa komitmen organisasi sebagai tingkat identitas diri seorang pegawai terhadap fakta-fakta dan harapan organisasi untuk memelihara keanggotaannya dalam organisasi tersebut.

\section{METODE}

Sesuai dengan permasalahan yang diteliti dan tujuan penelitian yang ingin dicapai, penelitian bersifat verifikasi hipotesis menggunakan studi kausalitas dengan teknik analisis jalur (path Analysis). Penelitian berlangsung dari Bulan Februari sampai Juni 2015. Populasi target dalam penelitian ini adalah seluruh guru bimbingan dan konseling SMP Negeri di DKI Jakarta. sementara populasi terjangkaunya adalah guru bimbingan dan konseling SMP Negeri di Kecamatan Pasar Minggu yang berjumlah 8 sekolah. Dari populasi terjangkau terpilih empat (4) sekolah yang diambil secara cluster random sampling. Dari empat sekolah terdapat 22 guru BK yang dijadikan responden dalam penelitian ini.

Penelitian ini menggunakan tiga instrumen yang berkaitan dengan variabel kepemimpinan, kepercayaan (trust), dan komitmen organisasi. Ketiga instrumen dibuat berdasarkan definisi operasional yang disintesiskan dari rumusan-rumusan definisi di atas. Definisi operasional variabel kepemimpinan (leadership) adalah perilaku seseorang ketika mengarahkan dan mempengaruhi bawahan dalam rangka mencapai tujuan organisasi yang terdiri dari indikator: 1) memberikan arahan; 2) melakukan supervisi;3) memberikan evaluasi; 4) memberikan penghargaan; 5) memberikan bimbingan.

Kepercayaan (trust) dalam penelitian ini mempunyai definisi operasional sebagai pengharapan dari pegawai untuk menerima otoritas berdasarkan harapan positif dari niat dan tindakan otoritas dalam kaitannya dengan pelaksanaan tugas, wewenang, dan tanggung jawab kepada orang lain yang secara operasional sesuai dengan pencapaian tujuan organisasi, dengan indikator: 1) ada harapan positif, 2) berperilaku positif, 3) memiliki keterbukaan informasi; 4) memiliki hubungan yang baik; 5) memberikan peluang untuk bertindak; 6) bersedia mengambil resiko.

Definisi operasional variabel komitmen organisasi adalah perasaan, keinginan, dan kepercayaan seseorang terhadap tujuan tujuan yang ingin diwujudkan dalam organisasinya. Komitmen organisasi terbagi tiga dimensi yaitu: 1) komitmen afektif, 2) komitmen berkelanjutan, dan 3) komitmen normatif.

\section{HASIL DAN PEMBAHASAN}

\section{Pengaruh Kepemimpinan Terhadap Komitmen Organisasi}

Berdasarkan hasil perhitungan koefisien jalur Kepemimpinan $\left(X_{1}\right)$ terhadap Komitmen Organisasi $\left(X_{3}\right)$ sebesar $\varrho_{31}=0,623$ dan koefisien korelasi $r_{31}=0,734$ dan diperoleh thitung $=11,24$, pada taraf signifikansi $\alpha=0,01$ dengan tabel $=2,6$ sehingga thitung $>$ tabel yaitu 11,24 > 2,6 maka korelasi berarti. Temuan ini sesuai dengan teori yang dikemukakan oleh Greenberg (2010, p. 310) yang menyatakan bahwa kepemimpinan yang efektif adalah kunci dari keberhasilan dan kesuksesan organisasi. Bukan hanya sekedar opini akan tetapi telah dibuktikan di banyak Negara di dunia bahwa pemimpin yang efektif menjadi faktor penentu keberhasilan sebuah organisasi. 
Banyak penelitian membuktikan pengunaan personal power sangat effektif digunakan untuk mempengaruhi. Terutama pengunaan expert dan refent power sangat berpengaruh positif terhadap kepuasan kerja karyawan dan komitmen organisasi. Dengan kedua kekuasaan ini seorang pemimpin dapat melakukan supervisi dan bimbingan kepada para bawahan. Sedangkan reward dan legitimate power dapat digunakan pemimpin untuk memberikan penghargaan dan membuat aturan-aturan yang menuju pencapaian tujuan organisasi. Sedangkan coercive power tidak dianjurkan untuk digunakan karna dapat berdampak negatif pada kepuasan kerja dan komitmen organisasi. Dengan kekuasaan dan kekuatan yang dimilikinya kepala sekolah dapat mempengaruhi semangat dan kerja guru BK, baik melalui supervisi, bimbingan, pemberian penghargaan, kesempatan, membina hubungan yang baik dengan para guru dan membuat aturan-aturan atau kebijakan-kebijakan yang akan mendorong guru-guru ke arah komitmen organisasi yang tinggi guna pencapaian tujuan sekolah. Dengan demikian hipotesis 1 yang menduga terdapat pengaruh langsung positif kepemimpinan terhadap kepercayaan dapat diterima. Hal ini mencerminkan semakin baik kepemimpinan kepala sekolah akan meningkatkan komitmen organisasi guru.

\section{Pengaruh Kepercayaan Terhadap Komitmen Organisasi}

Berdasarkan hasil perhitungan koefisien jalur Kepercayaan $\left(\mathrm{X}_{2}\right)$ terhadap Komitmen Organisasi $\left(\mathrm{X}_{3}\right)$ sebesar $\mathrm{Q}_{32}=0,161$ dan koefisien korelasi $\mathrm{r}_{32}=0,590$ dan diperoleh thitung $=$ 7,59, pada taraf signifikansi $\alpha=0,01$ dengan tabel $=2,6$ sehingga thitung $>$ tabel yaitu 7,59 $>2,6$ maka korelasi berarti. Temuan ini sesuai dengan pendapat yang dikemukakan Colquitt (2009, p. 244) bahwa kepercayaan berpengaruh positif terhadap komitmen organisasi.

Seseorang yang percaya tentunya akan lebih mudah untuk berkomitmen dibanding dengan sesorang yang tidak mempercayai tujuan organisasi adalah tujuannya. Pada dasarnya kepercayaan adalah perasaan seseorang terhadap suatu kondisi dan situasi maupun terhadap suatu kelompok atau organisasisehingga mereka bertahan atau mempertahankan keanggotaan pada organisasi tersebut. Lebih lanjut Colquitt (2009, p. 241) berpendapat bahwa kepercayaan yang dimiliki seseorang membuat dia merasa berkewajiban untuk mengembangkan perusahaan, karena karyawan merasa lebih percaya diri, dan bertangung jawab. Ketika peristiwa negatif terjadi terhadap perusahaan, karyawan akan bersedia menerima segala resiko yang datang dengan melanjutkan pekerjaan.

Guru yang memiliki kepercayaan terhadap organisasi sekolah, maka akan lebih bertanggung jawab dan percaya diri untuk mengembangkan sekolah, serta berani mengambil resiko dalam pencapai tujuan sekolah. Dengan demikian hipotesis 2 yang menduga terdapat pengaruh langsung positif kepercayaan terhadap komitmen organisasi dapat diterima. Hal ini mencerminkan semakin baik kepercayaan guru BK akan meningkatkan komitmen organisasi.

\section{Pengaruh Kepemimpinan Terhadap Kepercayaan}

Berdasarkan hasil perhitungan koefisien jalur Kepemimpinan $\left(X_{1}\right)$ terhadap Kepercayaan $\left(\mathrm{X}_{2}\right)$ sebesar $\mathrm{Q}_{21}=0,689$ dan koefisien korelasi $\mathrm{r}_{21}=0,686$ dan diperoleh thitung $=$ 9,82, pada taraf signifikansi $\alpha=0,01$ dengan tabel $=2,6$ sehingga thitung $>$ tabel yaitu 9,82 $>2,6$ maka korelasi berarti. Temuan ini didukung oleh pendapat McShane (2008:120) bahwa," trust means putting faith in the other person or group. It also a reciprpcal activity: to receive trust, you must demonstrate trust. Employees identify with and feel obliged to work for organization only when they trust its leaders. This explains why layoffs are one of the greatest 
blows to employee loyalty by reducing job security, companies reduce the trust employee have in their employers and employment relationship". Kepercayaan berarti menempatkan keyakinan seseorang dalam orang atau kelompok lain. Untuk menerima kepercayaan, seseorang harus menunjukkan kepercayaan pada orang lain. Staf/karyawan mengidentifikasi dengan dan merasa berkewajiban untuk bekerja bagi organisasi mereka hanya ketika percaya kepada pemimpinnya. Hal ini menjelaskan mengapa PHK adalah salah satu pukulan terbesar terhadap loyalitas karyawan karena dengan mengurangi karyawan bearti pemilik perusahaan gagal dalam hal kepercayaan, keamanan kerja, dan hubungan kerja.

Kinicki (2008, p. 235) menyatakan bahwa pemimpin adalah seseorang yang dapat melakukan investasi yang disengaja dalam hal kepercayaan. Mereka dapat memberikan orang alasan untuk percaya satu sama lain bukan alasan untuk saling menjatuhkan. Mereka bisa menolak untuk menghargai keberhasilan dan membangun perilaku tidak saling mempercayai. Dan mereka dapat menampilkan kepercayaan dalam setiap tindakan baik secara pribadi dan atas nama perusahaan. Sangat penting bagi kepala sekolah untuk membangun, menciptakan dan mendapat kepercayaan dari para guru BK, agar terjalin kerjasama yang baik dan saling mempercayai, menghargai, dengan para guru BK, maupun diantara sesama guru selaku rekan kerja.

\section{Pengaruh Kepemimpinan Terhadap Komitmen Organisasi melalui Kepercayaan}

Berdasarkan hasil perhitungan koefisien jalur Kepemimpinan $\left(X_{1}\right)$ terhadap Kepercayaan $\left(\mathrm{X}_{2}\right)$ sebesar $\mathrm{Q}_{21}=0,689$ dan koefisien korelasi $\mathrm{r}_{21}=0,686$ dan diperoleh thitung $=9,82$, pada taraf signifikansi $\alpha=0,01$ dengan tabel $=2,6$ sehingga thitung $>$ tabel yaitu 9,82 > 2,6 maka korelasi berarti. Temuan ini sesuai dengan teori yang dikemukankan Colquitt (2008, p. 441) bahwa kepemimpinan adalah pengunaan sumber daya untuk pengaruhi dan memimpin aktivitas para pengikut atau bawahan untuk mencapai tujuan yang dinginkan. Dalam mengarahkan para bawahan sebagai akibatnya akan terlihat pada interprestasi yang mucul pada pekerjaan, komitmen yang menjadi kunci keberhasilan, hubungan yang terjalin antar sesama bawahan, akses perusahaan dan dukungan dari berbagai kalangan.

Secara tersirat hasil di atas mengambarkan bahwa kepemimpinan yang dipercayai, akan mampu membangun kepercayaan dari para bawahan sehingga akan melahirkan komitmen utuk mewujudkan tujuan organisasi dan sekaligus juga akan melahirkan dukungan dari pihak luar. Demikian juga halnya dengan kepala sekolah, kepemimpinan yang baik dari seorang kepala sekolah akan membangun kepercayaan dari guru BK terhadap organisasi maupun pihak luar yang terkait dengan organisasi dan dengan sendirinya kan membangun komitmen organisasi dari guru bersangkutan.

\section{SIMPULAN}

Berdasarkan hasil pengolahan dan analisis data serta pengujian hipotesis dapat disimpulkan: 1) Hasil penelitian menyatakan bahwa terdapat pengaruh langsung positif kepemimpinan terhadap komitmen organisasi guru BK SMP Negeri di Kecamatan Pasar Minggu. 2) Hasil penelitian yang menyatakan bahwa tidak terdapat pengaruh langsung positif kepercayaan terhadap komitmen organisasi guru SMP Negeri di Kecamatam Pasar Minggu. 3) Hasil penelitian yang menyatakan bahwa terdapat pengaruh langsung positif kepemimpinan terhadap kepercayaan guru SMP Negeri di Kecamatan Pasar Minggu. 4) 
Hasil penelitian yang menyatakan bahwa terdapat pengaruh langsung positif kepemimpinan terhadap komitmen organisasi melalui kepercayaan.

Beberapa hal yang disarankan dalam penelitian ini sebagai berikut: 1) Agar guru, dalam hal ini guru BK (konselor) sebagai ujung tombak keberhasilan dunia pendidikan mampu meningkatkan kualitas kepercayaan baik terhadap diri sendiri maupun kepemimpinan atau otoritas, sehingga selalu melahirkan pikir dan sikap-sikap positif dalam diri guru BK; 2) Agar kepala sekolah selaku pimpinan disekolah senangtiasa memberikan arahan, bimbingan, supervisi, evaluasi maupun perhargaan secara rutin dan berkala guna meningkatkan kualitas dan kepercayaan guru organisasi yang akan mendorong loyalitas guru BK dan meningkatkan komitmen organisasi pada guru BK;3) Agar kepala sekolah sebagai pribadi yang menjadi panutan selalu memperlihatkan sikapsikap positif, santun, peduli dan bersahabat, serta senangtiasa meningkatkan keterampilan manajerialnya guna meningkatkan kualitas diri dan kepercayaan para bawahannya dan warga sekolah lainnya; 4) Dalam meningkatkan kualitas kepemimpinan kepala sekolah perlu adanya pelatihan-pelatihan manajerial yang rutin dan berkesinambungan untuk dilakukan oleh pihak Dinas Pendidikan sebagai wadah peningkatan potensi diri bagi kepala sekolah; dan 5) Hendaknya dilakukan penelitian lanjutan untuk mengetahui hubungan variabel-variabel yang belum diteliti selain kepemimpinan dan kepercayaan dengan komitmen organisasi khususnya pada guru BK SMP Negeri di Kecamatan Pasar Minggu.

\section{REFERENSI}

Andre, R. (2008). Organizational behavior: an introduction to your life in organizations. New Jersey: Pearson Prentice Hall.

Colquitt, J., Lepine, J. A., Wesson, M. J., \& Gellatly, I. R. (2011). Organizational behavior: Improving performance and commitment in the workplace. New York: McGraw-Hill Irwin.

Davis, K., \& Newstrom, J. W. (2002). Organizational behavior: Human behavior at work. New York: McGraw-Hill.

Greenberg, J. (2010). Managing behavior in organizations (Fifth edition). New Jersey: Pearson.

Kinicki, A. (2008). Organizational behavior: Core concepts. New York: McGraw-Hill.

Kreitner, R., \& Kinicki, A. (2008). Organizational behavior, key concepts, skill and best practices. New York: McGraw-Hill.

Komariah, A., \& Triatna, C. (2005). Visionary leadership, menuju sekolah efektif. Jakarta: Bumi Aksara.

McShane, S. L., \& Von Glinow, M. A. (2008). Organizational Behavior (Fourth edition). New York: McGraw-Hill. 
INDONESIAN JOURNAL OF EDUCATIONAL COUNSELING 2018, 2(2), 197-204

Muhidin, S. A., \& Abdurahman, M. (2009). Analisis korelasi, regresi dan jalur dalam penelitian. Bandung: Pustaka Setia.

Robbins, P. S., \& Judge, T. A. (2011). Organizational behavior (Fourteenth edition). New Jersey: Pearson Education.

Yukl, G. A. (1994). Leadership in organizations. New Jersey: Pearson Education. 